\title{
Determination of Shear Strength Parameters of Rock Mass using Back Analysis Methods and Comparison of Results with Empirical Methods
}

\author{
Ehsan Bakhtiyari, Ali Almasi, Akbar Cheshomi, Jafar Hassanpour
}

\begin{abstract}
In this study, using the collected data from 4 slope failures in one of the central mines of Iran, the shear strength parameters of jointed and crushed rock masses using back analysis method are calculated and its results are compared with the values obtained from the empirical methods. In this regard, firstly, the identification of failures is investigated and then geometrical and geological engineering parameters of slopes are collected and recorded by field survey. At this stage, using the Hoek-Brown criterion, shear strength parameters of the rock mass are estimated. Then, using appropriate software for slope stability analysis (limit equilibrium method software: SLIDE and numerical method software: FLAC), and assuming that safety factor is one, the shear strength parameters for sliding surfaces are determined. Finally, the results obtained from this analysis are compared with the results of the empirical methods and then suggestions are made to modify the input data of empirical method.
\end{abstract}

Index Terms-Back Analysis; Limit Equilibrium; Numerical Analysis; Hoek-Brown Criterion.

\section{INTRODUCTION}

Determining the appropriate values with a certain level of confidence for the shear strength parameters of rock mass is very important in the design and sustainability of structures constructed in rocks such as tunnels, mines, etc. Intact rock parameters and joint properties, control the response of the rock mass. The behavior of rock mass with a few joints and fractures is anisotropic, in which the rock mass strength depends on the number, direction, spacing and shear strength of discontinuities [1].

The direct measurement of the mechanical properties of jointed rock masses using laboratory experiments are far from precise due to the effect of sample dimensions, discontinuities, unknown geometry of the fracture system before testing and the inherent complexity of geometric parameters [2]. Laboratory tests carried out on a rock mass cannot cover all unknown parameters in site and requires several methods for reliable estimates [3]-[6]. Many researchers have studied the strength of jointed rock mass. Today, there are many methods for estimating the shear strength of rock mass. One of these methods is back analysis. In this method, geomechanical parameters of rock

Published on November 30, 2017

Ehsan Bakhtiyari is with the School of Geology, College of Sciences, University of Tehran, Tehran, Iran (e-mail: bakhtiar_66@ut.ac.ir).

Ali Almasi is with the School of Geology, College of Sciences, University of Tehran, Tehran, Iran (e-mail: ali.almasi@yahoo.com).

Akbar Cheshomi is the corresponding writer and he is assistant professor 9 School of Geology, College of Sciences, University of Tehran, Tehran, Iran (e-mail: a.cheshomi@ut.ac.ir).

Jafar Hassanpour is assistant professor, School of Geology, College of Sciences, University of Tehran, Tehran, Iran (e-mail: hassanpour@ut.ac.ir). mass can be obtained by knowing the failure mechanism and collecting the required information from the unstable slope [7]. This method is one of the most reliable methods in determining shear strength parameters in soil and rock slopes because it is a large-scale shear test and the values obtained from this method are more accurate than those obtained in the laboratory or in-situ test [8], [9].

Researchers often use numerical and limit equilibrium methods for back analysis. In selection of an appropriate method for back analysis, the process and mechanism of instability must be well understood [10]-[14]. According to the characteristics of the rocks, the stability analysis methods of rock slopes are classified into two general categories. The first category is used for hard jointed rocks and the second category is used for heavily jointed rocks or weak rock masses [15]. The limit equilibrium method is suitable for both categories. In the first group, with the limit equilibrium method, the shear strength parameters can be calculated form back analysis along the instability. But in the second category, the shear strength parameters are obtained by the methods which are developed for measuring stability of soil slopes [10], [16]. In limit equilibrium method, there is no possibility of examining internal deformities and progressive failures. For solving this problem, continuous and discontinuous numerical methods are commonly used [17].

In numerical modeling, it is possible to make an accurate prediction of deformation, the stability of slope, and load values; also, the model can have a broad insight into the responses of a system for parametric studies [18]. In numerical methods, shear strength reduction technique is usually used to slope stability analysis. In shear strength reduction technique, the shear strength parameters of soil, including cohesion and angle of internal friction are gradually reduced with a decreasing coefficient, until the slope becomes unstable. Finite Difference Method (FDM) is one of the most widely used numerical methods that can provide the necessary view needed for engineering judgment by reducing the remaining shear strength, changing the failure criterion for rock, calculating the stress-strain of slopes and evaluating displacement of sliding [19].

Another method used to determine the shear strength parameters is the empirical method of Hoek-Brown criterion. The Hook-Brown criterion is one of the most important criteria in rock mechanics, and this criterion can be used to determine the shear strength parameters. In this method, first, we should estimate the normal stresses on the failure plan with available methods of slope stability; then, calculate the shear strength parameters based on Hoek- 
Brown criterion and normal stresses [20]-[22].

In this paper, four slope failures in one of the central mines of Iran are identified. During field survey of the study area, using the field observations and laboratory studies, physical and mechanical properties of the rock masses in the mine area were determined. Then the shear strength parameters of the unstable rock masses are estimated using the back analysis method (limit equilibrium and numerical method) and their results are compared with values obtained from the empirical method.

\section{MATERIALS AND METHODS}

The research was carried out in one of the central mines of Iran. This mineral area is located in longitude between 55 $\circ 20$ 'and $55^{\circ} 24^{\prime}$ ' eastern, and latitude between $29^{\circ} 2$ 'to 29 $\circ 5$ ' north. Based on field studies in the studied area, four unstable slopes are identified, as described in Table I.

The mechanism of four identified instabilities is circular and characteristics of each failure including lithology of materials, height, gradient, mechanism of instability, and geomechanical condition of rock masses are provided in Table I. In Fig. 1 and 2, the location of 4 unstable rock masses is shown on a satellite image and Pitt plan. In Fig. 3 images of unstable slopes are shown.

TABLE I: LIST OF IDENTIFIED 4 UNSTABLE SLOPES

\begin{tabular}{|c|c|c|c|c|c|c|}
\hline $\begin{array}{l}\text { No. of } \\
\text { Failure }\end{array}$ & $\begin{array}{c}\text { Geologi } \\
\text { cal } \\
\text { Enginee } \\
\text { ring } \\
\text { Units }\end{array}$ & $\begin{array}{l}\text { Litholo } \\
\text { gy }\end{array}$ & $\begin{array}{c}\mathrm{He} \\
\text { igh } \\
\mathrm{t} \\
(\mathrm{m} \\
)\end{array}$ & $\begin{array}{c}\text { Gradi } \\
\text { ent } \\
\text { (degr } \\
\text { ee) }\end{array}$ & $\begin{array}{c}\text { Mechan } \\
\text { ism of } \\
\text { instabili } \\
\text { ty }\end{array}$ & $\begin{array}{l}\text { Geomechani } \\
\text { cal condition }\end{array}$ \\
\hline No.1 & CS-I & $\begin{array}{l}\text { Chlorit } \\
\text { e schist }\end{array}$ & 18 & 49 & $\underset{r}{\text { circula }}$ & $\begin{array}{c}\text { Severely } \\
\text { crushed } \\
\text { and } \\
\text { weathered }\end{array}$ \\
\hline No. 2 & CS-I & $\begin{array}{l}\text { Chlorit } \\
\text { e schist }\end{array}$ & 15 & 49 & $\begin{array}{c}\text { circula } \\
\mathrm{r}\end{array}$ & $\begin{array}{c}\text { Severely } \\
\text { crushed } \\
\text { and } \\
\text { weathered }\end{array}$ \\
\hline No. 3 & $\begin{array}{c}\text { CS-I, } \\
\text { M-I } \\
\text { (II) }\end{array}$ & $\begin{array}{c}\text { Magne } \\
\text { tite } \\
\text { schist }\end{array}$ & 15 & 50 & $\begin{array}{c}\text { circula } \\
\mathrm{r}\end{array}$ & $\begin{array}{l}\text { Jointed- } \\
\text { Blocked }\end{array}$ \\
\hline No. 4 & O-I (II) & $\begin{array}{c}\text { Hemati } \\
\text { te }\end{array}$ & 17 & 51 & $\begin{array}{c}\text { circula } \\
\mathrm{r}\end{array}$ & $\begin{array}{c}\text { Severely } \\
\text { crushed } \\
\text { and } \\
\text { weathered }\end{array}$ \\
\hline
\end{tabular}

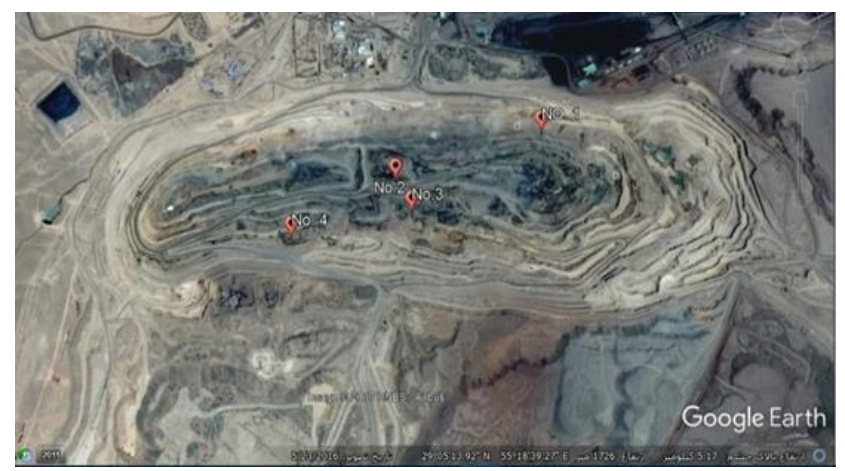

Fig.1. Location of unstable rock masses on satellite image (Google Earth 2016).

In Fig. 4, the flow diagram of study methods is shown. In the beginning, through the field survey, the failure slopes are identified and then the sliding surface properties are determined. Estimation of the shear strength parameters of the sliding surface is performed by back analysis method respectively by limit equilibrium method (Slide software)
[23], numerical method (Flac software) [24], and empirical method of Hoek-Brown (RocLab software) [25], and results are compared.

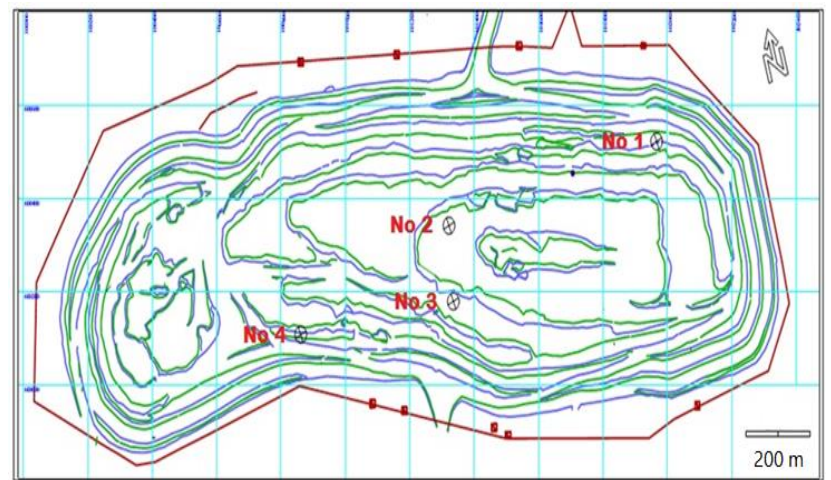

Fig.2. Location of unstable rock masses (circles with intersecting lines) on Pitt plan.
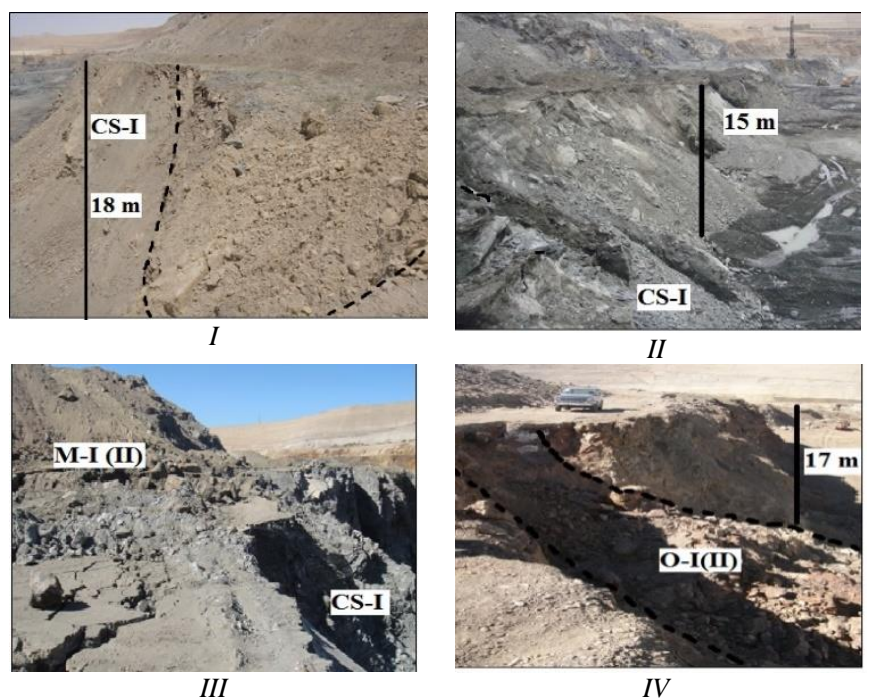

Fig.3. Images of unstable slopes: I- Failure No. 1 in engineering geology unit CS-I with lithology of chlorite schist to a height of 18 meters, IIFailure No. 2 in engineering geology unit CS-I with lithology of chlorite schist severely crushed and weathered to a height of 15 meters, III- Failure No. 3, the upper section in engineering geology units M-I (II) with magnetite lithology and lower section in CS-I engineering geology unit with chlorite schist lithology, IV- Failure No. 4 is mainly in engineering geology units O-I (II) with hematite lithology heavily crushed and 17 meters high.

Field survey from the study area and identification failure slopes in mine

Determining the characteristics of identified sliding surfaces and engineering parameters of failure slopes.
Estimation of shear strength parameters by back analysis method using limit equilibrium method (Slide software)
Estimation of shear strength parameters by back analysis method using numerical method (Flac software)
Estimation of shear strength parameters by back analysis method using empirical method (Hoek- Brown criterion)
Compare the results obtained from back analysis with the results of experimental methods

Fig.4. The flow diagram of study methods 


\section{GeologicAl EngineERING Property of UnStABle UNITS}

In the study area, 5 engineering geology units are identified and separated. In Table II, in addition to specifying each unit of rock, also structural features, values of RQD, basic RMR, GSI, strength properties including modulus of elasticity and Hoek-Brown constants are provided. The lithology of the studied rocks is determined by field surveys, sample preparation, and laboratory tests. Uniaxial compressive strength and deformation properties are determined by uniaxial compression tests in the laboratory. The RQD values for each unit are obtained with respect to the amount of recycled cores on the site; then, using the values of uniaxial compressive strength, RQD, condition, and distance between joints, RMR values are calculated for each unit. GSI values are estimated from field observations based on the structure of rock masses and surface conditions of joints on the GSI chart and finally, the Hook-Brown criterion constants are obtained using empirical equations and GSI values.

TABLE II: GEOMECHANICAL PROPERTIES OF ENGINEERING GEOLOGY UNITS

\begin{tabular}{|c|c|c|c|c|c|c|c|c|c|c|c|c|}
\hline No. & $\begin{array}{l}\text { Rock } \\
\text { Type }\end{array}$ & Lithology & Structure & $\begin{array}{c}\text { Rock } \\
\text { Strength } \\
(\mathrm{Mpa})\end{array}$ & RQD (\%) & RMR basic & GSI & $\begin{array}{c}\text { Em } \\
(\mathrm{Gpa})\end{array}$ & $\begin{array}{c}\text { Hoek_Brown } \\
(\mathrm{mb})\end{array}$ & $\begin{array}{c}\text { Hoek_Brown } \\
\text { (s) }\end{array}$ & $\begin{array}{c}\text { Hoek_Brown } \\
\text { (a) }\end{array}$ & $\begin{array}{l}\text { Fracture } \\
\text { Interpret }\end{array}$ \\
\hline 1 & CS-I & $\begin{array}{l}\text { Chlorite } \\
\text { schist }\end{array}$ & $\begin{array}{c}\text { very } \\
\text { blocky \& } \\
\text { disturbed }\end{array}$ & 30 & 12 & 32 & 30 & 0.6 & $6.74 \mathrm{E}-02$ & 8.57E-06 & $5.22 \mathrm{E}-01$ & F4 \\
\hline 2 & O-I & $\begin{array}{c}\text { Oxide } \\
\text { (Hematite) }\end{array}$ & $\begin{array}{c}\text { very } \\
\text { blocky \& } \\
\text { blocky }\end{array}$ & 35 & 65 & 45 & 50 & 1.0 & $5.62 \mathrm{E}-01$ & $2.40 \mathrm{E}-04$ & $5.06 \mathrm{E}-01$ & F3 \\
\hline 3 & O-II & $\begin{array}{c}\text { Oxide } \\
\text { (Hematite) }\end{array}$ & $\begin{array}{l}\text { very } \\
\text { blocky }\end{array}$ & 40 & 35 & 45 & 45 & 0.8 & 3.93E-01 & $1.04 \mathrm{E}-04$ & $5.08 \mathrm{E}-01$ & $\mathrm{~F} 3 \& \mathrm{~F} 4$ \\
\hline 4 & M-I & $\begin{array}{c}\text { Bottom } \\
\text { Magnetite }\end{array}$ & Blocky & 75 & 70 & 50 & 57 & 4.3 & $1.15 \mathrm{E}+00$ & $1.27 \mathrm{E}-03$ & 5.03E-01 & F3 \\
\hline 5 & M-II & $\begin{array}{c}\text { Bottom } \\
\text { Magnetite }\end{array}$ & Blocky & 100 & 70 & 55 & 60 & 4.9 & $1.15 \mathrm{E}+00$ & $1.27 \mathrm{E}-03$ & $5.03 \mathrm{E}-01$ & F3 \\
\hline
\end{tabular}

\section{INPUT PARAMETERS}

The input parameters of Slide software are presented in Table III. Input values of the Slide software include geometry of slope and unit weight of rock mass, which physical and mechanical properties of rock masses are obtained through laboratory experiments.

TABLE III: INPUT PARAMETERS OF SLIDE

\begin{tabular}{ccccc}
\hline \hline \multirow{2}{*}{ No. of slide } & & $\begin{array}{c}\text { Unsaturated Unit } \\
\text { Weight }(\mathrm{kN} / \mathrm{m} 3)\end{array}$ & $\begin{array}{c}\text { Saturated Unit } \\
\text { Weight }(\mathrm{kN} / \mathrm{m} 3)\end{array}$ & Water Surface \\
\hline No.1 & CS-I & 25 & - & None \\
No.2 & CS-I & - & 25 & Hu value 1 \\
No. 3 & CS-I, & 25 & 27 & Hu value 1 \\
No. 4 & M-I (II) & - & 40 & Hu value 1 \\
\hline \hline
\end{tabular}

The input parameters of the Flac software are presented in Table IV. Density, bulk module, shear module, tension strength and elastic module are calculated in the laboratory. The permeability of rock masses is determined by in situ tests. The difference between back analysis method in the numerical software of Flac and limit equilibrium software of Slide is that in the numerical method, unlike the equilibrium method, there is no possibility of imposing a precise failure plane in software. Therefore, it is necessary to carefully determine the values of cohesion and angle of internal friction until the failure plane has the maximum geometric similarity to the actual failure plane in the safety factor equal to one.

TABLE IV: INPUT PARAMETERS OF FLAC

\begin{tabular}{|c|c|c|c|c|c|c|c|c|c|}
\hline $\begin{array}{c}\text { No. of } \\
\text { slide }\end{array}$ & Rock type & $\begin{array}{c}\text { Density } \\
(\mathrm{Kg} / \mathrm{m} 3)\end{array}$ & Bulk Module (Pa) & $\begin{array}{c}\text { Shear Module } \\
(\mathrm{Pa})\end{array}$ & Tension $(\mathrm{Pa})$ & Poision Ratio & $\mathrm{K}(\sigma \mathrm{h} / \sigma \mathrm{n})$ & $\begin{array}{c}\text { Permeabil } \\
\text { ity }(\mathrm{m} / \mathrm{s})\end{array}$ & Erm $(\mathrm{Pa})$ \\
\hline No.1 & CS-I & 2500 & $1.835 \mathrm{e} 8$ & $3.976 \mathrm{e} 8$ & $2 \mathrm{e} 3$ & 0.3 & 1.1 & - & $477.01 \mathrm{e} 6$ \\
\hline No.2 & CS-I & 2500 & $2.792 \mathrm{e} 8$ & $1.288 \mathrm{e} 8$ & $1 \mathrm{e} 3$ & 0.3 & 1.1 & $2 e-5$ & $335.08 \mathrm{e} 6$ \\
\hline \multirow{2}{*}{ No. 3} & CS-I & 2500 & $1.01863 \mathrm{e} 9$ & $4.70138 \mathrm{e} 8$ & $8 \mathrm{e} 3$ & 0.3 & 1.1 & $2 e-5$ & $1125.65 \mathrm{e} 6$ \\
\hline & M-I (II) & 4000 & $1.01863 \mathrm{e} 9$ & $4.70138 \mathrm{e} 8$ & $8 \mathrm{e} 3$ & 0.3 & 1.1 & $2 e-5$ & $1125.65 \mathrm{e} 6$ \\
\hline No. 4 & O-I (II) & 3800 & $3.6237 \mathrm{e} 8$ & $1.6728 \mathrm{e} 8$ & $1 \mathrm{e} 3$ & 0.3 & 1.1 & - & $434.85 \mathrm{e} 6$ \\
\hline
\end{tabular}

Input parameters for RocLab software are provided in Table V. The values of the Hoek-Brown constants were

calculated from field observations and using existing empirical equations.

TABLE V: INPUT PARAMETERS OF ROCLAB

\begin{tabular}{|c|c|c|c|c|c|c|c|c|c|}
\hline \multirow[b]{2}{*}{ No. of slide } & \multicolumn{4}{|c|}{ Hoek-Brown Classification } & \multicolumn{3}{|c|}{ Hoek-Brown Criterion } & \multicolumn{2}{|c|}{ Failure Envelope Range } \\
\hline & $\begin{array}{c}\text { Sig } \\
\operatorname{ci}(\mathrm{Mpa})\end{array}$ & GSI & $\mathrm{mi}$ & $\mathrm{D}$ & $\mathrm{m}_{\mathrm{b}}$ & $\mathrm{S}$ & A & $\begin{array}{c}\text { Unit Weight } \\
(\mathrm{MN} / \mathrm{m} 3)\end{array}$ & $\begin{array}{c}\text { Slope Height } \\
(\mathrm{m})\end{array}$ \\
\hline No.1 & 20 & $15-25$ & 8 & 0.8 & 0.0683945 & $2.44 \mathrm{e}-6$ & 0.543721 & 0.025 & 18.7 \\
\hline No.2 & 15 & $10-20$ & 8 & 0.7 & 0.0749534 & $4.46679 \mathrm{e}-006$ & 0.561101 & 0.025 & 14.5 \\
\hline No. 3 & 30 & $25-35$ & 8 & 0.7 & 0.170894 & $3.92748 \mathrm{e}-005$ & 0.522344 & 0.032 & 14.6 \\
\hline No. 4 & 25 & $10-20$ & 8 & 0.7 & 0.0749534 & $4.46679 \mathrm{e}-006$ & 0.561101 & 0.038 & 15.1 \\
\hline
\end{tabular}




\section{ESTIMATION THE SHEAR STRENGTH PARAMETERS OF FAILURES}

\section{A. Limit equilibrium method}

In the limit equilibrium method, the profile of slopes is drawn in the Slide software with respect to the geometric characteristics of slope and sliding surface, and input parameters entered into Slide software according to Table III. By putting the geological engineering parameters in the corresponding software, the values of shear stress and effective stress at the moment of siding are calculated, considering safety factor equal to 1 for all failures. In Fig. 5, the profile of unstable slopes with the values of shear stress and effective stress is shown. In all profiles, 25 pieces was considered to be analyzed in Slide software. In the failure No. 1, height of bench is more than 18 meters and it is executed with a gradient of 49 degrees. Tension cracks are formed and developed at the upper surface of bench and effects of initial movement are evident. In failure No. 2, depth of the tension cracks was about 1 meter which these cracks were saturated with water, and it seems that water plays very important role in instability of this slope. The gradient angle of failure No. 2 is approximately at the same with failure No. 1; besides, failure No. 2 is saturated and failure No. 1 is dry and the material involved in both failures are similar (engineering geology unit CS-I), so it is expected that the shear strength parameters in failure No. 2 would be much higher than shear strength parameters failure No. 1 in order to stay stable. In failure No. 3, sliding surface is started from a depth of about 3 meters from a tension crack and after the occurrence of sliding; a steep to a height of about 3 meters is created. These tension cracks partially are filled with water. It should be noted that the sliding surface has not passed through the magnetite unit; therefore, only weight of this layer has been affected by the sliding mass and its weight is included in the calculations. The sliding surface failure No. 4 is passed from a height of about 3 meters to the heel of the bench and the slope height is about 12 meters.

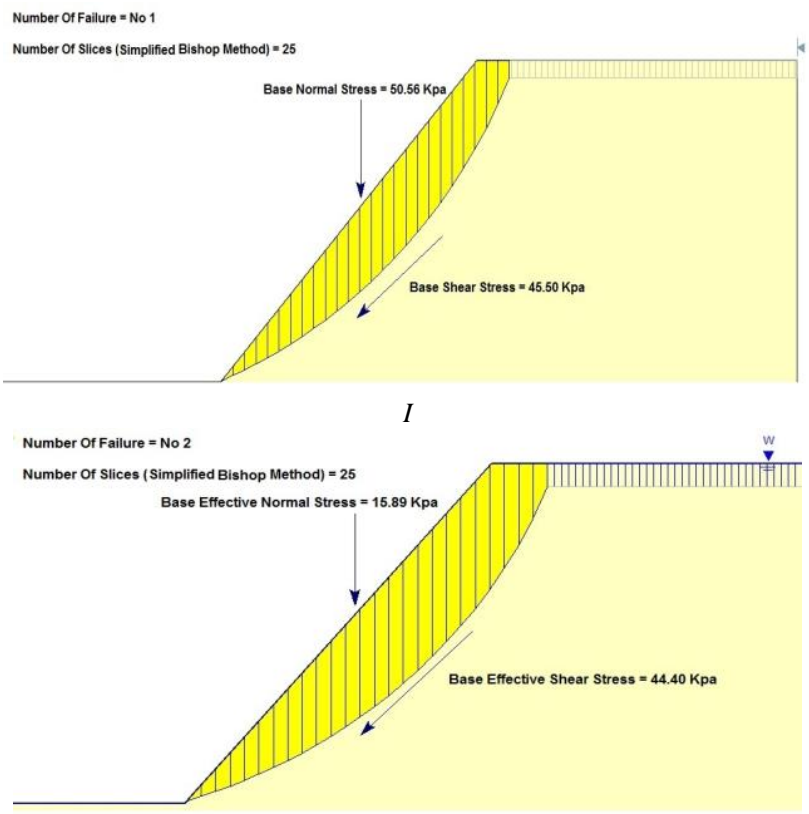

II

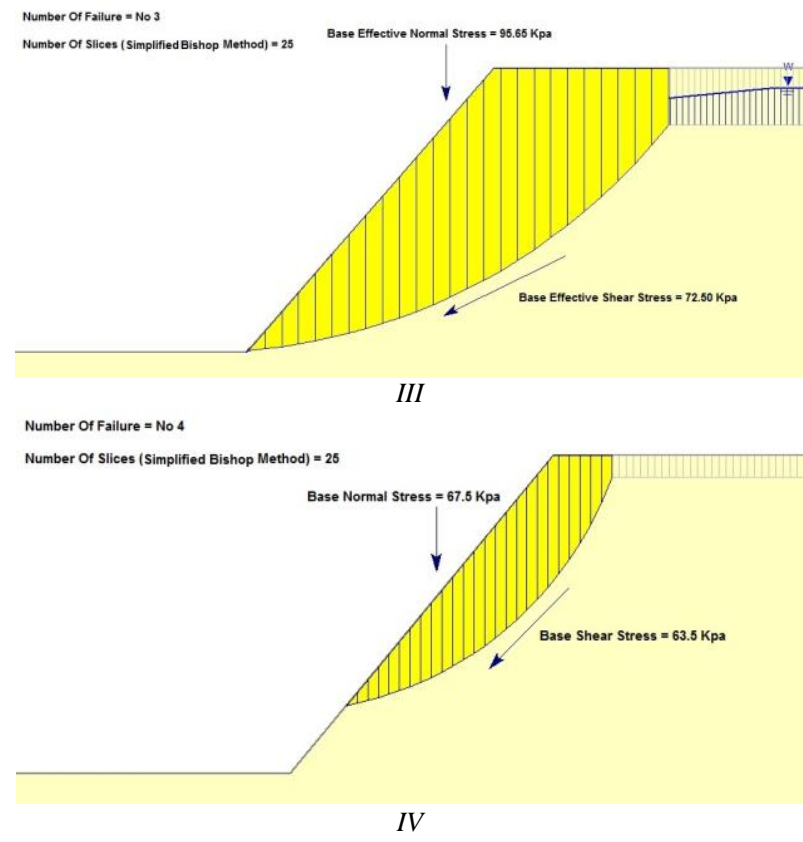

Fig. 5. Profile of failures with normal stress and shear stress: I- failure No.1, II- failure No. 2, III- failure No. 3, IV-failure No. 4.

The results of back analysis on the profile of failures using SLIDE software are shown in Fig. 6. In this figure, all possible values for parameters of $\mathrm{C}$ (cohesion) and $\varphi$ (angle of internal friction) for rock mass with a plus symbol (blue points) are shown and values of parameters $C$ and $\varphi$ for safety factor equal to one (limit equilibrium) with square symbols (red points) are shown for any failure. According to the output diagram of Slide software, the values of cohesion and angle of internal friction at the moment of failure are obtained. The values of parameters $\mathrm{C}$ and $\varphi$ for failure No. 1 is estimated between $9-16 \mathrm{KN} / \mathrm{m} 2$ and $31-36$ degrees, for failure No. 2 between $26-32 \mathrm{KN} / \mathrm{m} 2$ and 37-49 degrees, for failure No. 3 between $41-51 \mathrm{KN} / \mathrm{m} 2$ and 13-18 degrees, for failure No. 4 between 16-26 KN/m2 and 28-34 degrees, respectively.
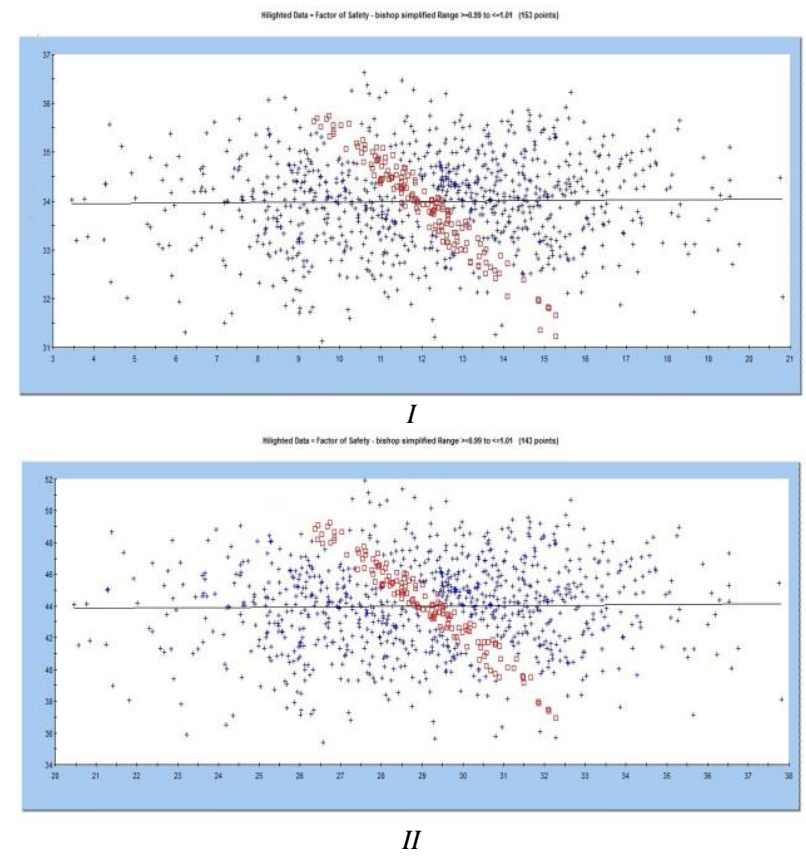

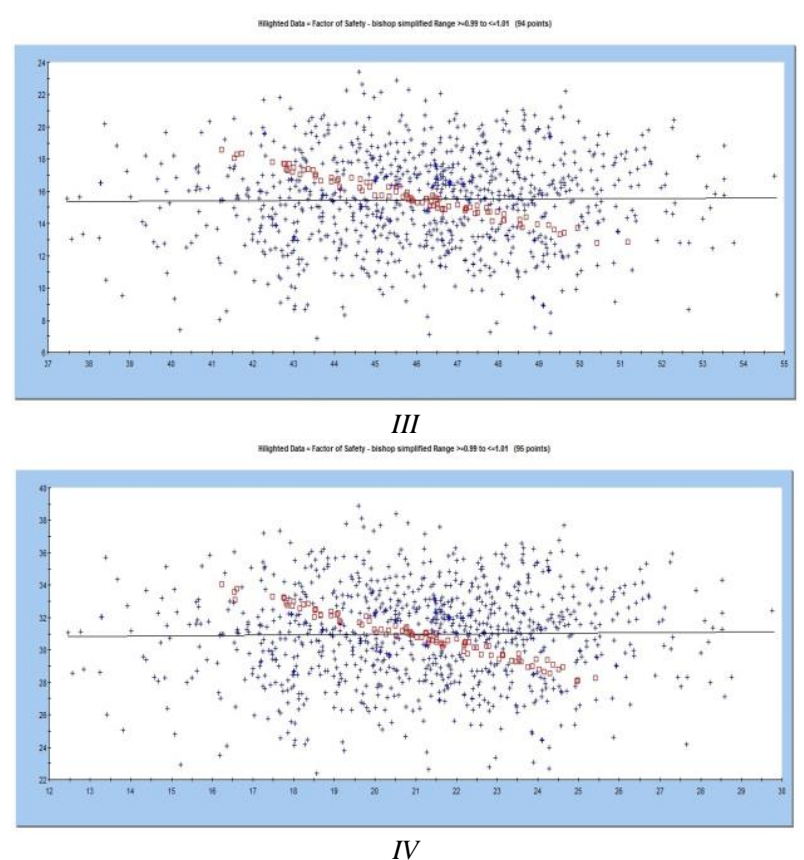

Fig. 6. Distribution of all values of $\mathrm{C}$ and $\varphi$ for rock mass by plus symbols (blue points) and $\mathrm{C}$ and $\varphi$ values for safety factor equal to one by square symbols (red points): I- failure No.1, II- failure No. 2, III- failure No. 3, IVfailure No. 4 .

\section{B. Numerical method}

In this method, at first, according to the height and gradient of slopes, models are made; then, according to Table IV, the input parameters are entered into Flac software and back analysis numerically is performed for all failures. In the Flac software, with the change of cohesion and angle of internal friction, the best sliding surface, which its distance from the edge of bench is equal to distance of tension crack from the edge of bench and also its safety factor is equal to 1 , is obtained and the values of cohesion and angle of internal friction in this case is for failure mode. The values obtained for cohesion and angle of internal friction are presented in Table VI. In Fig.7, outputs of Flac software are shown for all failures. These figures show the points with the highest shear strain. In fact, these points indicate the sliding surface of failures.

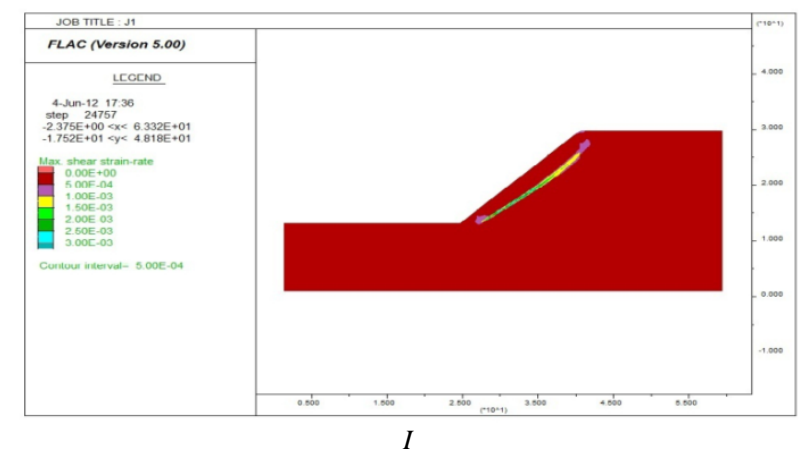

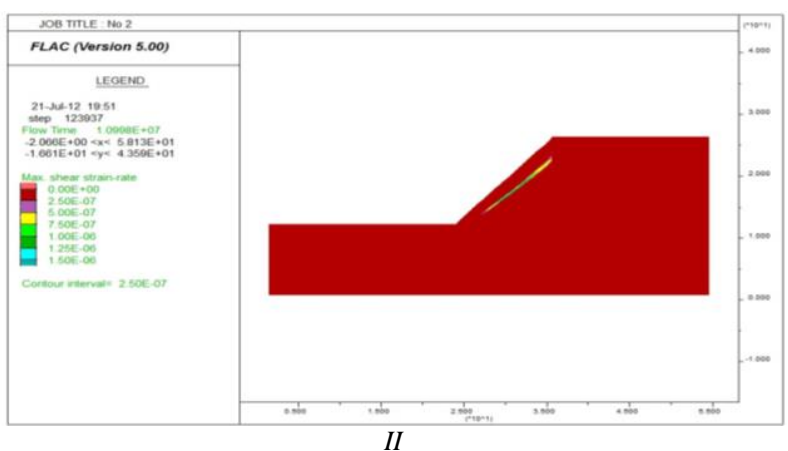
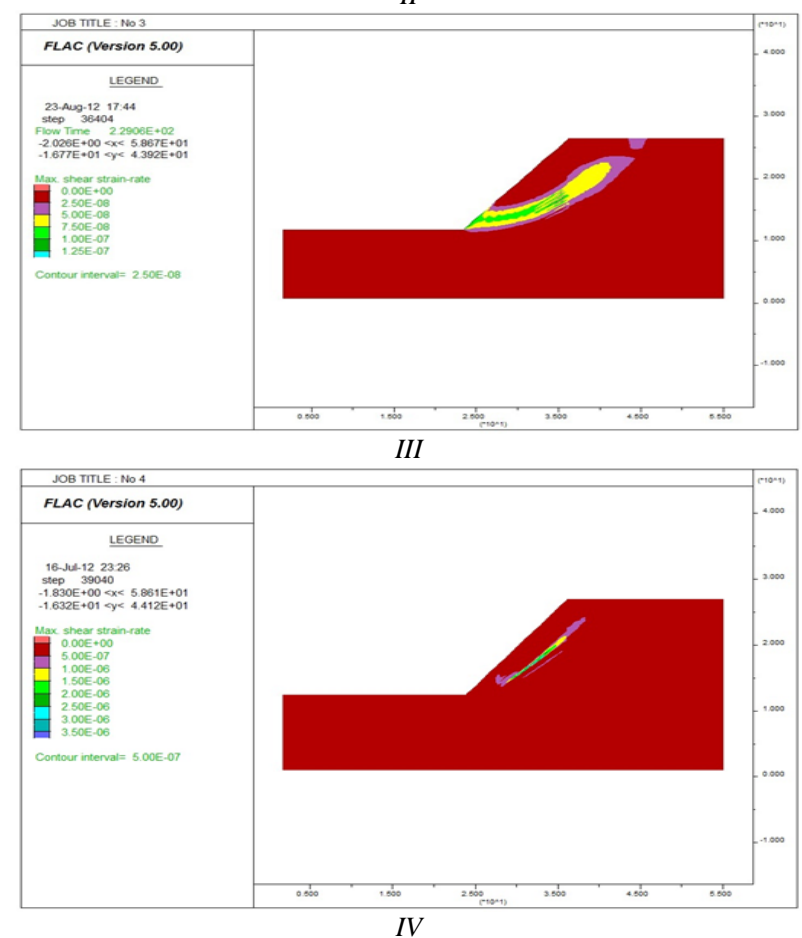

Fig. 7. Output of Flac with maximum shear strain points in a safety factor equal to one that shows the geometry of sliding surface.: I- failure No.1, IIfailure No. 2, III- failure No. 3, IV-failure No. 4.

\section{Empirical method}

In the empirical method of Hoek-Brown criterion, according the Table $\mathrm{V}$, input parameters for RocLab software are entered. Accordingly, the values for parameters of $\mathrm{C}$ (cohesion) and $\varphi$ (angle of internal friction) can be estimated for the normal stresses at the sliding surface. Fig. 8 shows the output plot of the RocLab software for failure No. 1, 2, 3, and 4, respectively. As seen in the Fig. 8, the values of these parameters are estimated according to the normal stresses at the sliding surface.

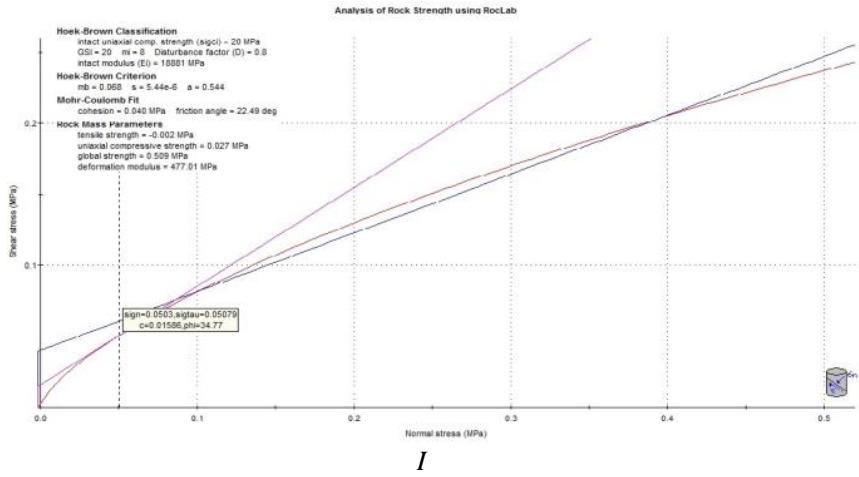



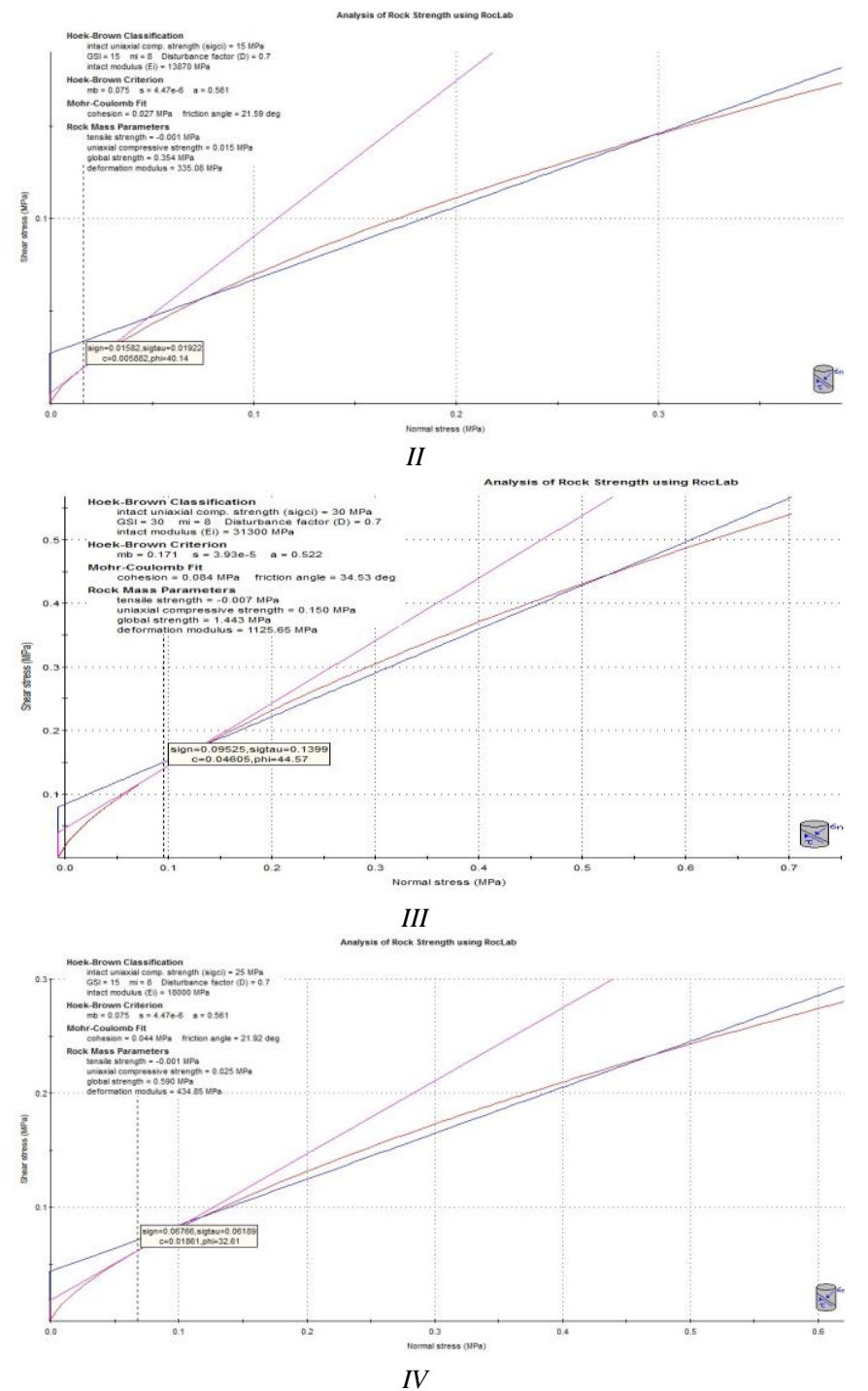

Fig. 8. The values for parameters of $\mathrm{C}$ (cohesion) and $\varphi$ (angle of internal friction) obtained by the Hoek-Brown method.: I- failure No.1, II- failure No. 2, III- failure No. 3, IV- failure No. 4.

Estimation of shear strength parameters by Hoek-Brown's empirical method for failures No. 1, 2, 3, and 4 is similarly done, with the results of all of them shown in Table VI.

TABLE VI: THE VALUES OF THE SHEAR STRENGTH PARAMETERS OBTAINED BY BACK ANALYSIS METHOD AND EMPIRICAL METHOD FOR FAILURES NO. 1, 2,3 , AND 4

\begin{tabular}{|c|c|c|c|c|c|c|}
\hline \multirow{3}{*}{ 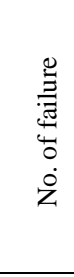 } & \multicolumn{6}{|c|}{ Shear Strength Parameters Of The Rock Mass. } \\
\hline & \multicolumn{3}{|c|}{ Cohesion $(\mathrm{kPa})$} & \multicolumn{3}{|c|}{ Angle of Friction (degree) } \\
\hline & 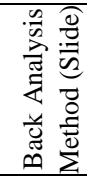 & 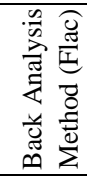 & 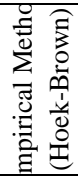 & 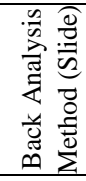 & 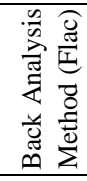 & 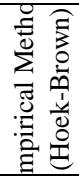 \\
\hline No.1 & $9-16$ & $10-17$ & 16 & $31-36$ & $31-38$ & 34 \\
\hline No.2 & $26-32$ & $27-34$ & 6 & $37-49$ & $36-48$ & 40 \\
\hline No. 3 & $41-51$ & $43-52$ & 46 & $13-18$ & $13-19$ & 44.5 \\
\hline No. 4 & $16-26$ & $16-26$ & 18 & $28-34$ & $30-36$ & 32 \\
\hline
\end{tabular}

\section{COMPARISON OF THE VALUES OBTAINED FROM THREE METHODS}

According to Fig. 9, there is a good agreement between results obtained from the three methods. It is safe to say that reason for relative increase in values of these parameters in the numerical method (FLAC software) in comparison with limit equilibrium method (SLIDE software) is mainly due to the difference in analysis method in which the FLAC software uses the strength reduction method to estimate the shear strength parameters; while the SLIDE software uses limit equilibrium method to estimate these values [26] Therefore, numerical methods give values of shear strength parameters more conservatively, yet more realistic. Also, amounts of parameters of cohesion and angle of internal friction obtained from the Hoek-Brown method are found within the defined range for both methods (numerical and limit equilibrium method) which this factor, not only verifies calculation of the Hoek-Brown criterion in this failure, but also confirms accuracy of input parameters in this criterion.

In failure No. 2, the values of shear strength parameters obtained by back analysis method (both limit equilibrium and numerical method) have a fairly good agreement and overlap. However, the values of cohesion and angle of internal friction obtained from the Hoek-Brown criterion is very different from two other methods for failure No. 2. The reason for this difference is that underground water has reduced effective stress and this reduction changed these values in the Hoek-Brown criterion. However, consequence of effective stress reduction is increasing values of shear strength parameters at the moment of instability. In other words, in order to start a sliding in a saturation slope, values of the shear strength parameters are much higher than those of a slope in the dry area. This factor is taken into account in both limit equilibrium and numerical analyzes, while it is not taken into account in Hoek-Brown criterion.

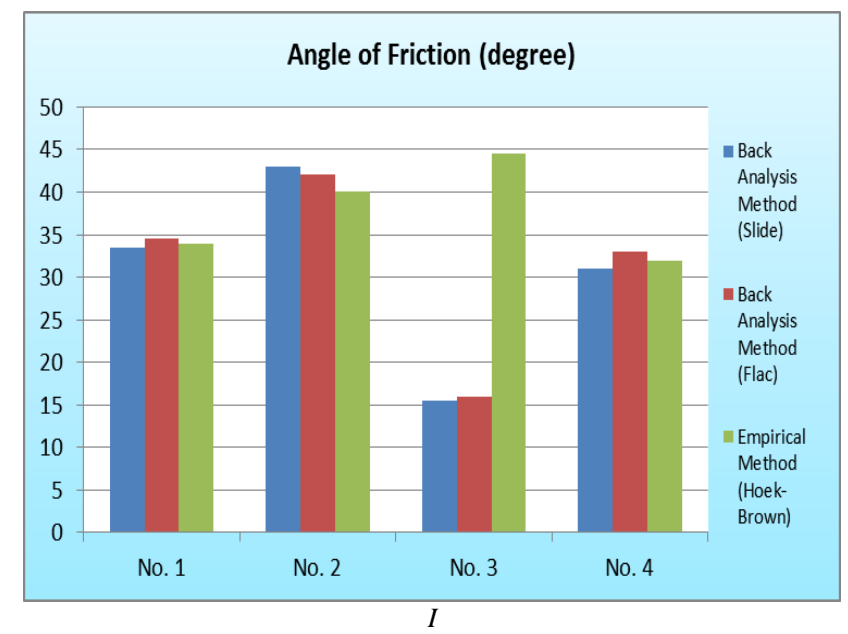




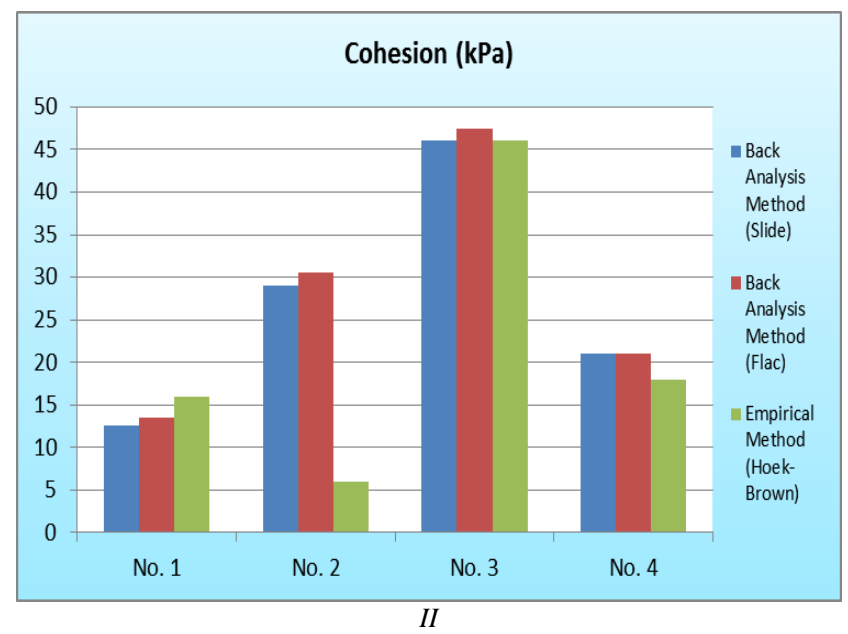

Fig. 9. Comparison of the values of I- the angle of internal friction; II- the cohesion obtained by back analysis and empirical method.

In failure No. 3, like failure No. 2, values of shear strength parameters obtained by back analysis method (both limit equilibrium and numerical method) have a fairly good agreement and overlap. Also, in this failure, considering that groundwater is considered as an effective parameter in sliding, the Hoek-Brown criterion is ineffective because it cannot properly consider role of water. In this failure, groundwater has significantly increased the amount of angle of internal friction in the Hoek-Brown criterion at the moment of sliding.

In failure No. 4, comparison of the shear strength parameters obtained from the three methods has shown a relatively good correlation between these values. Also, in this failure, like failure No. 1, 2, and 3 the shear strength parameters in the numerical method are determined slightly higher than limit equilibrium method, which is due to the difference in analysis method.

\section{CONCLUSION}

In this study, by studying 4 unstable slopes in one of the central mines of Iran, 5 geological engineering units including of Chlorite-Schist (CS-I), lower Magnetite (M-I (II)) and Hematite (O-I (II)) are identified. Field surveys showed that in all 4 failures, sliding surface is circular and materials are severely weathered and they have a lot of discontinuities. This weathering and discontinuity has caused rock masses to be similar to soil materials.

By combining the results from field observations and laboratory tests, engineering properties of materials for failures are determined. Then, shear strength parameters of the sliding surface using back analysis method by three methods of limit equilibrium, numerical and empirical are obtained. The range of shear strength parameters in four failures is compared. There are fairly good agreement and overlap between the results of limit equilibrium, numerical and empirical methods in failures which occurred on dry slopes. This confirms accuracy of the input parameters in the Hoek-Brown method. Therefore, it can be said that due to the simplicity of the Hoek-Brown method in dry slopes, using this method can provide acceptable results.

In failures occurred in saturation slopes, although there is good agreement between the results obtained from limit equilibrium and numerical methods, there is a significant difference between the results of these two methods and those of empirical method. The reason is that presence of water reduces the effective stress and increases the shear strength parameters at the moment of the sliding, and the Hoek-Brown criterion does not consider this increase in the shear strength parameters during the sliding in its calculations. Therefore, using Hoek-Brown criterion in saturation slopes should be carried out with caution and accompanied by limit equilibrium and numerical analysis. Anyway, in both failure No. 2 and 3, the Hoek-Brown criterion did not provide appropriate values for shear strength parameters and usage of this criterion is not recommended for obtaining shear strength parameters in similar hydrogeological conditions.

\section{REFERENCES}

[1] E. Hoek, "Strength of jointed rock masses," Geotechnique, vol. 33, no. 3, pp. 187-223, 1983.

[2] M. N. Bidgoli, Z. Zhao, \& L. Jing, Numerical evaluation of strength and deformability of fractured rocks, Journal of Rock Mechanics and Geotechnical Engineering, vol. 5, no. 6, pp. 419-430, 2013.

[3] M. Singh, K. S. Rao, and T. Ramamurthy, "Strength and deformational behaviour of a jointed rock mass," Rock Mechanics and Rock Engineering, vol. 35, no. 1, pp. 45-64, 2002.

[4] M. Singh, and K. S. Rao, "Bearing capacity of shallow foundations in anisotropic non-Hoek-Brown rock masses," Journal of geotechnical and geoenvironmental engineering, vol. 131, no. 8, pp.1014-1023, 2005.

[5] M. Singh, and K. S. Rao, "Empirical methods to estimate the strength of jointed rock masses," Engineering Geology, vol. 77, no. 1, pp.127$137,2005$.

[6] M. Singh, and B. Singh, "High lateral strain ratio in jointed rock masses," Engineering Geology, vol. 98, no. 3, pp.75-85, 2008

[7] S. Sakurai, S. Akutagawa, K. Takeuchi, M. Shinji, and N. Shimizu, "Back analysis for tunnel engineering as a modern observational method," Tunnelling and Underground Space Technology, vol. 18 , no. 2, pp.185-196, 2003.

[8] M. Cai, H. Morioka, P. K. Kaiser, Y. Tasaka, H. Kurose, M. Minami, and T. Maejima, "Back-analysis of rock mass strength parameters using AE monitoring data," International Journal of Rock Mechanics and Mining Sciences, vol. 44, no. 4, pp.538-549, 2007.

[9] A. Saeidi, V. Maazallahi, and A. Rouleau, "Assessment of slide surface and pre-slide topography using site investigation data in back analysis," International Journal of Rock Mechanics and Mining Sciences, vol. 88, p. 29-33, 2016.

[10] M. Sharifzadeh, M. Sharifi, and S. M. Delbari, "Back analysis of an excavated slope failure in highly fractured rock mass: the case study of Kargar slope failure (Iran)," Environmental Earth Sciences, vol. 60 , no. 1 , pp.183-192, 2010.

[11] S. J. Harris, R. P. Orense, and K. Itoh, "Back analyses of rainfallinduced slope failure in Northland Allochthon formation," Landslides, vol. 9, no. 3, pp.349-356, 2012.

[12] L. L. Zhang, J. Zhang, L. M. Zhang, and W. H. Tang, "Back analysis of slope failure with Markov chain Monte Carlo simulation," Computers and Geotechnics, vol. 37, no. 7, pp.905-912, 2010.

[13] J. C. Jiang, and T. Yamagami, "A new back analysis of strength parameters from single slips," Computers and Geotechnics, vol. 35, no. 2, pp.286-291, 2008.

[14] S. M. Ng, M. A. M. Ismail, and I. Abustan, "Back analysis of slope failure using finite element with point estimate method (FEM-PEM)," Journal of Civil Engineering Research, vol. 4, no. 3A, pp.31-35, 2014.

[15] H. Sonmez, R. Ulusay, and C. Gokceoglu, "A practical procedure for the back analysis of slope failures in closely jointed rock masses,' International Journal of Rock Mechanics and Mining Sciences, vol. 35, no. 2, pp.219-233, 1998 .

[16] D. Stead, E. Eberhardt, and J. S. Coggan, "Developments in the characterization of complex rock slope deformation and failure using numerical modeling techniques," Engineering Geology, vol. 83, no. 1, pp.217-235, 2006

[17] Itasca Consulting Group. FLAC 3D-Fast Lagrangian Analysis of Continua in 3 Dimensions, User's manual, Minneapolis, 2005.

[18] W. K. Song, and K. C. Han, "Optimal design of highway slopes in a highly weathered rock," In 9th ISRM Congress. International Society for Rock Mechanics, 1999. 
[19] W. Ming, F. Xundong and L. Huan, "Reducing method for intensity of slope stability analysis," Civil Engineering, vol. 20, no. 1, pp. 4952, 2006 (in Chinese).

[20] X. L. Yang, and J. H. Yin, "Slope equivalent Mohr-Coulomb strength parameters for rock masses satisfying the Hoek-Brown criterion," Rock Mechanics and Rock Engineering, vol. 43, no. 4, pp.505-511, 2010.

[21] J. Shen, S. D. Priest, and M. Karakus, "Determination of MohrCoulomb shear strength parameters from generalized Hoek-Brown criterion for slope stability analysis, Rock mechanics and rock engineering, vol. 45, no. 1, pp.123-129, 2012.

[22] J. Shen, M. Karakus, and C. Xu, "Direct expressions for linearization of shear strength envelopes given by the Generalized Hoek-Brown criterion using genetic programming," Computers and Geotechnics, vol. 44, pp.139-146, 2012.

[23] Rocscience Ltd. (2002) SLIDE-2D Slope Stability Analysis for Rock and Soil Slopes. Toronto, Ontario, www.rocscience.com

[24] Itasca Consulting Group Inc. FLAC (FastLagrangian Analysis of Continua), Version 5.0, Minneapolis, MN.

[25] Rocscience Ltd. (2002) ROCLAB Software for Calculating HoekBrown Rock Mass Strength. Toronto, Ontario, www.rocscience.com

[26] L. R. Alejano, A. M. Ferrero, P. Ramírez-Oyanguren, and M. A Fernández, "Comparison of limit-equilibrium, numerical and physical models of wall slope stability," International Journal of Rock Mechanics and Mining Sciences, vol. 48, no. 1, pp.16-26, 2011.

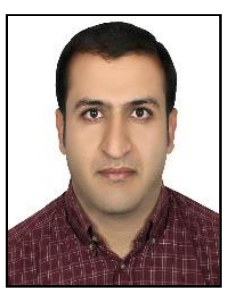

Ehsan Bakhtiyari was born in 1987, Iran. He has graduated with a M.Sc. in Engineering Geology in the field of slope stability from University of Tehran in 2013. Also, he has B.Sc. degree in Geology from Shahid Beheshti University.

$\mathrm{He}$ has been an instructor at the University of Applied Science and Technology since 2014. He has experience working in the field of geotechnical engineering for 2 years. His main research interest is slope stability analysis in soil and rock. He developed a geological classification for parts of Tehran's alluvium with respect to excavation using numerical and limit equilibrium method in 2013 Moreover, he used back analysis method for estimating the shear strength parameter of jointed rock mass.

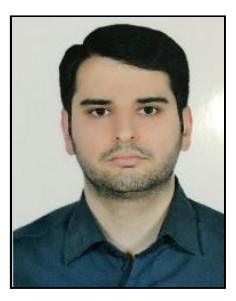

Ali Almasi was born in 1987, Iran. He has graduated with a M.Sc. in Engineering Geology from University of Tehran in 2012. Also, he has a B.Sc. degree in Geology from Shahid Beheshti University.

He has been working in National Iranian Drilling Company (NIDC) since 2012. He has experience working in fields of Geomechanics, Geological Forecasting Programmer, Well site Geologist in NIDC. His main research interest is wellbore instability problems, well site geology, log analysis, geological forecast program and slope stability in rock and soil. Currently, he is studying and working on geomechanics of petroleum reservoirs.

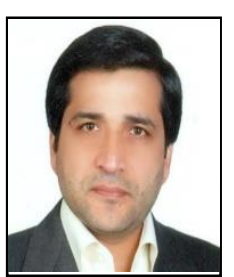

Akbar Cheshomi was born in Iran. He has graduated with a Ph.D. degree in Engineering Geology from Tarbiat Modares University in 2006. Also, he has graduated with a M.Sc. in Engineering Geology from Tarbiat Modares University in 1997. He has been working as an assistant professor at University of Tehran from 2010.

He has more than 20 years' experience in engineering geology and geotechnical engineering activities in various fields. His research interests include slope stability, classification of soils based on engineering geology parameters, soil improvement, site investigation, Laboratory and in-situ tests. Also, he has more than 30 articles in international journals.

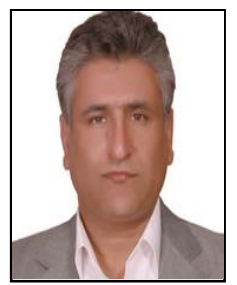

Jafar Hassanpour was born in Iran. He has graduated with a Ph.D. degree in Engineering Geology from Tarbiat Modares University in 2009. Also, he has graduated with a M.Sc. in Engineering Geology from Tarbiat Modares University in 1997. He has been working as an assistant professor at University of Tehran from 2013.

He has experience over 18 years of combined study, research, management, and teaching in the fields of engineering geology, rock and soil engineering. His main research interest are execution and post construction analysis in the tunneling for urban and highway transportation, water conveyance tunnels, dams, power plant stations, open pit mines, slopes and landslides and generally, infrastructures. 